\title{
$\beta$ cell expression of IGF-I leads to recovery from type 1 diabetes
}

\author{
Mónica George, Eduard Ayuso, Alba Casellas, Cristina Costa, Jean Christophe Devedjian, \\ and Fatima Bosch
}

Department of Biochemistry and Molecular Biology, School of Veterinary Medicine, and Center of Animal Biotechnology and Gene Therapy, Universitat Autònoma de Barcelona, Bellaterra, Spain

Address correspondence to: Fatima Bosch, Department of Biochemistry and Molecular Biology,

Edifici V, Universitat Autònoma de Barcelona, 08193 Bellaterra, Spain.

Phone: 34-93-5811043; Fax: 34-93-5812006; E-mail: fatima.bosch@uab.es.

Received for publication April 29, 2001, and accepted in revised form March 26, 2002.

\begin{abstract}
Patients with type 1 diabetes are identified after the onset of the disease, when $\beta$ cell destruction is almost complete. $\beta$ cell regeneration from islet cell precursors might reverse this disease, but factors that can induce $\beta$ cell neogenesis and replication and prevent a new round of autoimmune destruction remain to be identified. Here we show that expression of IGF-I in $\beta$ cells of transgenic mice (in both C57BL/6-SJL and CD-1 genetic backgrounds) counteracts cytotoxicity and insulitis after treatment with multiple low doses of streptozotocin (STZ). STZ-treated nontransgenic mice developed high hyperglycemia and hypoinsulinemia, lost body weight, and died. In contrast, STZtreated C57BL/6-SJL transgenic mice showed mild hyperglycemia for about 1 month, after which they normalized glycemia and survived. After STZ treatment, all CD-1 mice developed high hyperglycemia, hypoinsulinemia, polydipsia, and polyphagia. However, STZ-treated CD-1 transgenic mice gradually normalized all metabolic parameters and survived. $\beta$ cell mass increased in parallel as a result of neogenesis and $\beta$ cell replication. Thus, our results indicate that local expression of IGF-I in $\beta$ cells regenerates pancreatic islets and counteracts type 1 diabetes, suggesting that IGF-I gene transfer to the pancreas might be a suitable therapy for this disease.
\end{abstract}

J. Clin. Invest. 109:1153-1163 (2002). DOI:10.1172/JCI200212969.

\section{Introduction}

Type 1 diabetes results from autoimmune destruction of the insulin-producing $\beta$ cells of pancreatic islets (1). Patients are identified after diabetes onset, when $\beta$ cell destruction is nearly complete. Insulin-replacement therapy allows diabetic patients to lead active lives, but most of them develop severe secondary microvascular pathology in the retina and renal glomerulus, and macrovascular and neurological complications (2). Although islet transplantation leads to successful insulin delivery, the shortage of donors and potential elimination of transplanted islets by autoimmune reactions are serious limitations (3). Approaches using surrogate cells to deliver insulin (engineered cell lines derived from $\beta$ cells or non- $\beta$ cells) are also being developed $(4,5)$. Nevertheless, these approaches will only provide replacement therapies. Recovery from type 1 diabetes requires $\beta$ cell regeneration from islet cell precursors and prevention of recurring autoimmunity. Adult islet cells are constantly being replaced by a slow turnover, probably from a few islet cells that retain their replicative capacity (6). Furthermore, ductal stem cells in the adult pancreas differentiated into endocrine cells and generated an islet $(7,8)$. Several growth factors induce cell replication in islets in vitro (9) or are mitogenic to ductal epithelial cells (10-13).
IGF-I has insulin-like metabolic effects and stimulates cell proliferation and differentiation (14). Circulating IGF-I is mainly synthesized by the liver, but it is also produced locally in most tissues, including the pancreas, where it acts in an autocrine/paracrine manner $(14,15)$. Increased IGF-I expression is also localized to focal areas of regeneration in pancreatectomized rats and dogs $(16,17)$, suggesting that IGF-I contributes to the growth or differentiation of pancreatic tissue. Islet cells contain IGF-I receptors (18). Mice lacking both IGF-I receptors and insulin receptor substrate-2 (IRS-2) show marked reduction of $\beta$ cell mass and die from diabetes due to $\beta$ cell insufficiency (19), indicating that IGF-I receptors couple to IRS- 2 in the pancreatic islet to mediate $\beta$ cell development, proliferation, and survival. In addition, IGF-I increases glucose-dependent $\beta$ cell proliferation in vitro (20). IGF-I-induced $\beta$ cell proliferation depends on IRS-mediated activation of phosphatidylinositol 3'-kinase (PI 3'-kinase) (20).

IGF-I is also considered a survival factor that has a widespread antiapoptotic effect on many death signals. The main signaling pathway for IGF-I receptor-mediated protection from apoptosis originates with the interaction of the IGF-I receptor with the IRS-1 (21), leading to activation of PI $3^{\prime}$-kinase and Akt/protein kinase $B(22-24)$, and the phosphorylation and inactivation of BAD (25), a member of the Bcl-2 family of 
proteins. The IGF-I receptor also activates alternative pathways for protection, one through activation of mitogen-activated protein kinase (MAPK) (26) and another through the activation of Raf- 1 and its translocation to the mitochondria (26). All three pathways result in $\mathrm{BAD}$ phosphorylation. The presence of multiple antiapoptotic pathways may explain the remarkable efficiency of the IGF-I receptor in protecting cells from apoptosis. Thus, it has been shown that IGF-I treatment protects islets against cytokine-mediated inhibition of insulin secretion, stimulation of nitric oxide formation, and cell death by apoptosis (27-29). Similarly, adenoviral gene transfer of IGF-I to human islets in vitro prevents IL- $1 \beta$-mediated nitric oxide formation and IL-1 $\beta$-induced, Fas-mediated apoptosis (30). The anti-inflammatory and antiapoptotic role of IGF-I in pancreatic $\beta$ cells is dependent on PI 3'-kinase activation (29). In addition, before diabetes onset, subcutaneous administration of recombinant IGF-I to young nonobese diabetic (NOD) mice reduces diabetes incidence and pancreatic insulitis $(31,32)$. In NOD mice injected with autoreactive $\mathrm{T}$ cells from diabetic NOD mice, IGF-I treatment reduces massive $\mathrm{T}$ cell invasion of islets and delays the onset and decreases the incidence of diabetes (32).

In this study we have examined in vivo whether the expression of IGF-I specifically in $\beta$ cells induces islet regeneration and counteracts type 1 diabetes. We used transgenic mice expressing mouse IGF-I gene under the control of the rat insulin promoter-I (RIP-I/IGF-I) (33, 34 ), in both C57BL/6-SJL and CD-1 genetic backgrounds. These mice were treated with multiple low doses of streptozotocin (STZ). This treatment induces insulitis (35), the extent of which depends on genetic background, the expression of cytokines in islets (36), and $\beta$ cell death by apoptosis (37). Furthermore, STZ treatment induces $\beta$ cell production of reactive oxygen intermediates and nitric oxide (38), which are involved in $\beta$ cell destruction $(39,40)$. We found that STZ-treated transgenic mice overexpressing IGF-I in $\beta$ cells can counteract cytotoxicity and insulitis, regenerate endocrine pancreas, and recover from type 1 diabetes.

\section{Methods}

Construction of the RIP-I/IGF-I chimeric gene and generation of transgenic mice. To obtain the RIP-I/IGF-I chimeric gene, a $0.72-\mathrm{kb} E c o \mathrm{RI}$ fragment containing the entire mouse IGF-I cDNA (33) was introduced at the EcoRI site of the second exon of the $\beta$-globin gene in a RIP-I- $\beta$-globin vector (34). The 3.4-kb SacI-XhoI fragment containing the entire chimeric gene was microinjected into fertilized mouse eggs from a C57BL/6-SJL background. At 3 weeks of age, the animals were tested for the presence of the transgene by Southern blot analysis of tail DNA $(10 \mu \mathrm{g})$ digested with EcoRI (data not shown). Transgenic mice expressing the chimeric gene RIP-I/IGF-I with a C57BL/6-SJL genetic background were also backcrossed to CD-1 mice (Charles River, Wilmington, Massachusetts, USA), and male mice of the N4 genera- tions were used. Mice were fed ad libitum with a standard diet (Panlab S.A., Barcelona, Spain) and kept under a light-dark cycle of 12 hours. Animals were killed and samples were taken between 1 and 2 hours after lights on. When stated, 2-month-old transgenic mice expressing the chimeric gene RIP-I/IGF-I of both C57BL/6-SJL and $\mathrm{CD}-1$ genetic background were given, on 5 consecutive days, an intraperitoneal injection of STZ (50 $\mathrm{mg} / \mathrm{kg}$ ), dissolved in $0.1 \mathrm{M}$ citrate buffer ( $\mathrm{pH} 4.5$ ) immediately before administration. Non-STZ-treated mice were injected only with the citrate buffer.

RNA analysis. Total RNA was obtained from whole pancreas (TriPure Isolation Reagent; Roche Molecular Biochemicals, Mannheim, Germany), and RNA samples $(30 \mu \mathrm{g})$ were electrophoresed on a $1 \%$ agarose gel containing $2.2 \mathrm{M}$ formaldehyde. Northern blot was hybridized to an $\alpha^{32}$ P-labeled 0.72-kb EcoRI-EcoRI fragment containing the entire IGF-I cDNA, a 0.36$\mathrm{kb} S m a \mathrm{I}-X h o \mathrm{I}$ fragment of the human insulin cDNA, or a $1.3-\mathrm{kb} E c o \mathrm{RI}-E c o$ RI fragment corresponding to rabbit $\beta$-actin cDNA.

Immunohistochemistry. For immunohistochemical detection of IGF-I, insulin, glucagon, somatostatin, and pancreatic polypeptide, pancreata from nontransgenic and transgenic mice were fixed for 12-24 hours in formalin, embedded in paraffin, and sectioned. Sections were then incubated overnight at $4^{\circ} \mathrm{C}$ with a rabbit anti-rat IGF-I antibody (GroPep Pty Ltd., Adelaide, Australia) diluted at 1:100, with a guinea pig anti-porcine insulin antibody (Sigma Chemical Co., St. Louis, Missouri, USA) at 1:100 dilution, with a rabbit anti-human glucagon antibody (ICN Biomedicals Inc., Irvine, California, USA) at 1:4000 dilution, with a rabbit anti-human somatostatin antibody (ICN Biomedicals Inc.) at 1:2000 dilution, or with a rabbit anti-human pancreatic polypeptide antibody (ICN Biomedicals Inc.) at 1:2000 dilution. As secondary antibodies, rabbit anti-guinea pig IgG, coupled to peroxidase (Roche Molecular Biochemicals), or biotinylated goat anti-rabbit antibody and $\mathrm{ABC}$ complex (Vector Laboratories Inc., Burlingame, California, USA), were used. The $3^{\prime} 3^{\prime}$ diaminobenzidine was used as the substrate chromogen. Sections were counterstained in Mayer's hematoxylin. To study the colocalization of IGF-I and insulin in islets of transgenic mice, FITC-labeled goat anti-rabbit (Southern Biotechnology Associates Inc., Birmingham, Alabama, USA) or TRITC-conjugated rabbit anti-guinea pig (Sigma Chemical Co.) were used as secondary antibodies. The latter secondary antibody was also used in $\beta$ cell apoptosis and $\beta$ cell neogenesis detection. For immunohistochemical detection of cytokeratin, sections of pancreas were incubated with a mouse anti-human cytokeratin antibody (DAKO Corp., Carpinteria, California, USA) at 1:50 dilution and treated with the Mouse on Mouse Immunodetection Kit (Vector Laboratories Inc.). Afterward, sections were incubated with StreptavidinFITC (Invitrogen Ltd., Paisley, United Kingdom). 


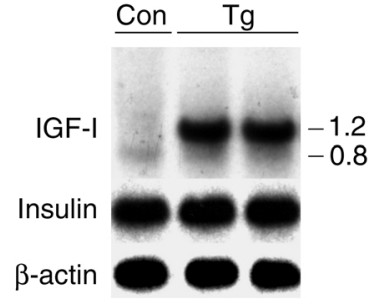

Figure 1

Expression of IGF-I and insulin in the pancreas of transgenic mice (C57BL/6-SJL genetic background). Total cellular RNA was obtained from nontransgenic (Con) and transgenic $(\mathrm{Tg})$ mice and analyzed by Northern blot as indicated in Methods. Two transcripts were detected in the pancreas of transgenic mice when hybridized with IGF-I probe. The $0.8-\mathrm{kb}$ transcript came from the expression of the endogenous gene, and the 1.2-kb transcript came from the expression of the transgene and was polyadenylated at the end of the $\beta$-globin gene.

Determination of $\beta$ cell replication. To measure the percentage of $\beta$ cell replication, mice were intraperitoneally injected with 5-bromo-2-deoxyuridine (BrdU) (Sigma Chemical Co.), $100 \mathrm{mg} / \mathrm{kg}$ body weight. Most of the BrdU is taken up and incorporated into DNA by 1 hour after injection (41). Because of the slow turnover of $\beta$ cells (42), animals were killed 8 hours after injection and BrdU-positive $\beta$ cells were measured. Paraffin sections $(5 \mu \mathrm{m})$ were double-stained for non- $\beta$ cells, with a cocktail of antisera (anti-glucagon, anti-somatostatin, and anti-pancreatic polypeptide), and for BrdU, with a mouse anti-BrdU mAb (Sigma Chemical Co.) at 1:1000 dilution, followed by a peroxidase-conjugated anti-mouse IgG. On these sections, the mantle of non- $\beta$ cells shows red cytosolic staining, while the BrdU-positive cells have dark-brown nuclei. At least 1000 islet $\beta$ cell nuclei were counted in each pancreas section. Data are expressed as the percentage of BrdU-positive $\beta$ cell nuclei per total number of $\beta$ cell nuclei per 8 hours.

Morphometric analysis. For morphometric analysis, pancreas was obtained from nontransgenic and transgenic mice, and immunohistochemical detection of insulin was performed in six sections $(2-3 \mu \mathrm{m})$, separated by $100 \mu \mathrm{m}$. The area $\left(\mathrm{mm}^{2}\right)$ of islet and the area of each section were measured using a Nikon Eclipse E800 microscope (Nikon Corp., Tokyo, Japan) connected to a video camera with a color monitor and to an image analyzer (analySIS 3.0; Soft Imaging

\section{Figure 2}

Immunohistochemical analysis of IGF-I, glucagon, and insulin expression in islets. IGF-I (a, d, $\mathbf{g}$, and $\mathbf{j})$, insulin ( $\mathbf{b}$, $\mathbf{e}, \mathbf{h}, \mathbf{k}, \mathbf{m}$, and $\mathbf{n})$, and glucagon $(\mathbf{c}, \mathbf{f}, \mathbf{i}$, and $\mathbf{I})$ staining of representative sections of pancreas before $(\mathbf{a}-\mathbf{f})$ and 3 months after (g-n) STZ treatment. Nontransgenic mice (Con): $\mathbf{a}-\mathbf{c}$ and $\mathbf{g}-\mathbf{i}(\times 400)$ and $\mathbf{m}(\times 40)$; transgenic mice (Tg): $\mathbf{d}-\mathbf{f}$ and $\mathbf{j}-\mathbf{I}(\times 400)$ and $\mathbf{n}(\times 40)$.
System Corp., Lakewood, Colorado, USA). The percentage of $\beta$ cell area in the pancreas was calculated by dividing the area of all insulin-positive cells in one section by the total area of this section and multiplying this ratio by 100 . The $\beta$ cell mass was calculated by multiplying the pancreas weight by the percentage of $\beta$ cell area. Neogenesis of $\beta$ cells was determined similarly, but only insulin-positive cells in ducts per pancreas section were counted. To determine $\beta$ cell size, the mean cross-sectional area of all individual cells in the ducts was measured in each section using an image analyzer. To calculate the percentage of $\beta$ cell area in one section, the number of $\beta$ cells in ducts was multiplied by the $\beta$ cell size and divided by the total area of this section and this ratio was multiplied by 100 . The mass of the duct-associated $\beta$ cell was calculated by multiplying the pancreas weight by the percentage of $\beta$ cell area.

Detection of apoptosis. Apoptotic cells were identified in deparaffinized pancreatic sections using TUNEL (In Situ cell death detection kit; Roche Molecular Biochemicals). Dual staining with TUNEL and insulin was performed. Nuclei were counterstained with Hoechst (Hoechst no. 332588; Sigma Chemical Co.). TUNEL/insulin double positive cells per section were counted. Results are expressed as percentage of double positive cells per total $\beta$ cells. At least 1000 nuclei per pancreas were counted, and five animals per group were used.
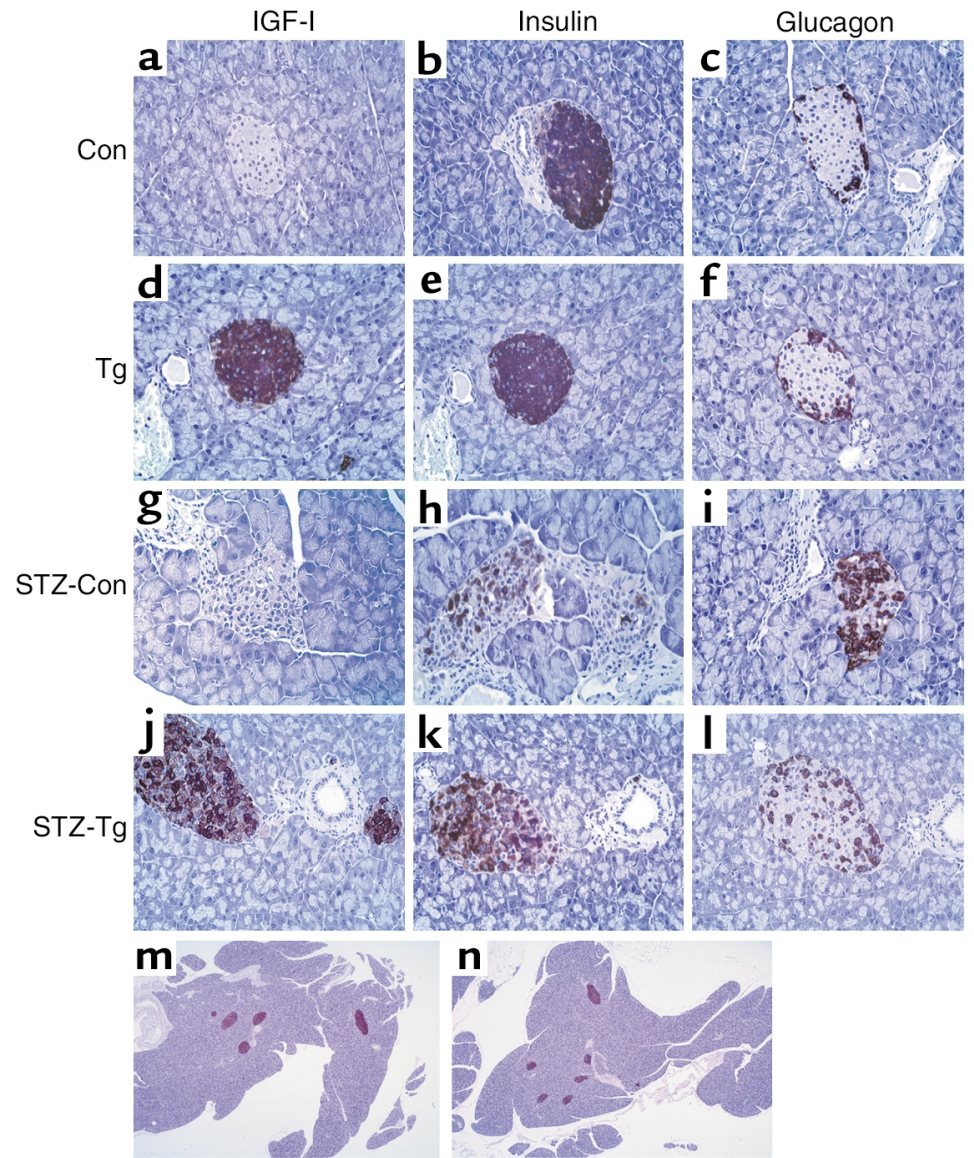


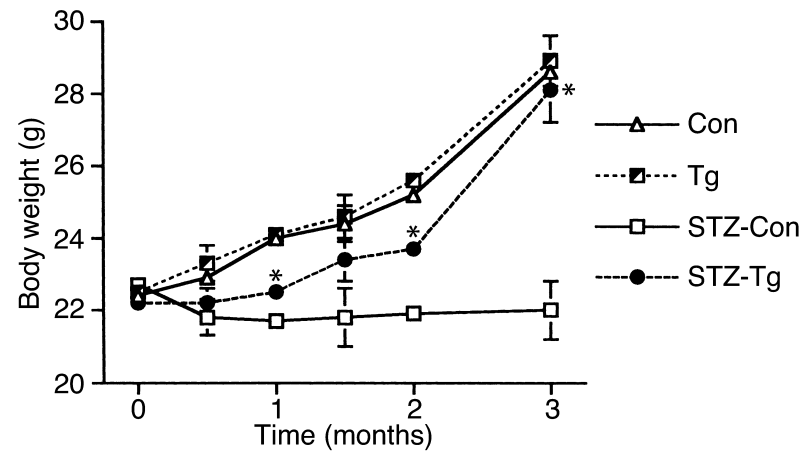

Figure 3

Changes in body weight of nontransgenic (Con; $n=10$ ) and transgenic $(\mathrm{Tg} ; n=12)$ mice and STZ-treated nontransgenic (STZ-Con; $n=10$ ) and transgenic (STZ-Tg; $n=15)$ mice. Results are mean \pm SEM of the indicated mice. ${ }^{*} P<0.05$ vs. STZ-treated nontransgenic mice.

Hormone and metabolite assays. Insulin and IGF-I serum concentrations were determined by RIA (insulin, CIS Biointernational, Gif-Sur-Yvette, France; IGF-I, Nichols Institute Diagnostics, San Juan Capistrano, California, USA). Blood glucose levels were measured with a Glucometer Elite analyzer (Bayer AG, Leverkusen, Germany). The $\beta$-hydroxybutyrate levels in serum were measured by the $\beta$-hydroxybutyrate dehydrogenase technique (D-3-Hydroxybutiric acid; Roche Molecular Biochemicals). Serum triglycerides were determined enzymatically (TRIG; Medical Analysis Systems Inc., Camarillo, California, USA). Serumfree fatty acids were measured by the acyl-CoA synthase and acyl-CoA oxidase method (Wako Chemicals $\mathrm{GmbH}$, Neuss, Germany). To determine pancreatic insulin content, whole pancreata were removed from the mice, weighed, and homogenized in $20 \mathrm{vol}$ of cold acidic ethanol ( $75 \%$ ethanol, $1.5 \%$ concentrated $\mathrm{HCl})$ followed by 48 hours of agitation at $4{ }^{\circ} \mathrm{C}$. Afterward, insulin was quantified in the supernatants of the samples by RIA (CIS Biointernational).

Statistical analysis. All values are expressed as the means \pm SEM. Statistical analysis was carried out using the Student-Newmann-Keuls test. Differences were considered statistically significant at $P<0.05$.

\section{Results}

Expression of IGF-I in $\beta$ cells of transgenic mice. The RIP-I/ IGF-I chimeric gene was microinjected to mouse embryos, and two founder mice (C57BL/6-SJL genetic background) were obtained. The studies presented below were performed in line 1 of transgenic mice, which carried about 50 intact copies of the transgene, as analyzed by Southern blot (data not shown). Adult mice express very low levels of IGF-I mRNA in pancreas, and four major transcripts of 0.8-1.2, 1.9, 4.7, and $7.5 \mathrm{~kb}$ can be detected (43). The pancreata of transgenic mice showed high levels of IGF-I mRNA, and two main transcripts $(0.8$ and $1.2 \mathrm{~kb})$ were detected when Northern blots were hybridized with IGF-I cDNA (Figure 1). The $1.2-\mathrm{kb}$ transcript came from the expression

of the transgene, and it was polyadenylated at the end of the $\beta$-globin gene. The $0.8-\mathrm{kb}$ transcript came from the expression of the endogenous gene, and it was present in the pancreata of both nontransgenic and transgenic mice. No expression of the transgene was noted in liver or muscle of the transgenic mice (data not shown). Furthermore, transgenic islets showed high IGF-I immunostaining, while no IGF-I was detected in nontransgenic mice (Figure 2, a and d). However, similar concentrations of serum IGF-I were observed in transgenic $(\mathrm{Tg})$ and nontransgenic (non- $\mathrm{Tg}$ ) mice $(\mathrm{Tg}$, $182 \pm 14 \mathrm{ng} / \mathrm{ml}$; non- $\mathrm{Tg}, 205 \pm 8 \mathrm{ng} / \mathrm{ml})$. These results suggest that IGF-I acted in a paracrine/autocrine manner within the islets. Pancreas from nontransgenic and transgenic mice showed similar levels of insulin mRNA (Figure 1), and no differences were observed in islet insulin (Figure 2, b and e) or glucagon (Figure 2, $\mathrm{c}$ and f) immunoreactivity. Moreover, 2-month-old transgenic mice presented similar insulinemia ( $\mathrm{Tg}, 30 \pm 1$ $\mu \mathrm{U} / \mathrm{ml}$; non- $\mathrm{Tg}, 31 \pm 1.5 \mu \mathrm{U} / \mathrm{ml})$, glycemia $(\mathrm{Tg}, 148 \pm 6$ $\mathrm{mg} / \mathrm{dl}$; non- $\mathrm{Tg}, 147 \pm 4 \mathrm{mg} / \mathrm{dl}$ ), and body weight (Figure 3) to those of nontransgenic mice. Morphometric analysis of pancreata of these transgenic and nontransgenic mice showed similar $\beta$ cell mass ( $\mathrm{Tg}$, $0.83 \pm 0.05 \mathrm{mg}$; non- $\mathrm{Tg}, 0.80 \pm 0.07 \mathrm{mg}$ ). Transgenic mice were healthy, did not develop tumors, and had normal lifespan and reproductive life.

Counteraction of diabetic byperglycemia by IGF-I expression in $\beta$ cells. To determine whether IGF-I expression in $\beta$ cells counteracts diabetic hyperglycemia, 2 -monthold nontransgenic and transgenic mice were intraperitoneally injected with low doses of STZ. Nontransgenic mice showed a blood glucose concentration of over $600 \mathrm{mg} / \mathrm{dl}$, the upper limit of measurement (Figure 4a). Although transgenic mice became hyperglycemic after STZ treatment, the blood glucose levels rose to about $300 \mathrm{mg} / \mathrm{dl}$, remained high for about 2 months, and then returned to normal levels (Figure 4a). Three months after STZ treatment, nontransgenic mice had low levels of serum insulin, while transgenic

a

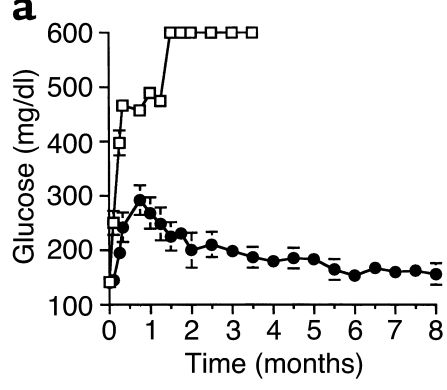

Figure 4

(a) Blood glucose levels before and after STZ treatment of mice. Glucose concentration was determined as indicated in Methods. Squares, nontransgenic mice $(n=15)$; circles, transgenic mice $(n=15)$. (b) Percent survival of nontransgenic (squares; $n=20)$ and transgenic (circles; $n=20$ ) mice after STZ treatment. Results are mean \pm SEM of the indicated mice. 

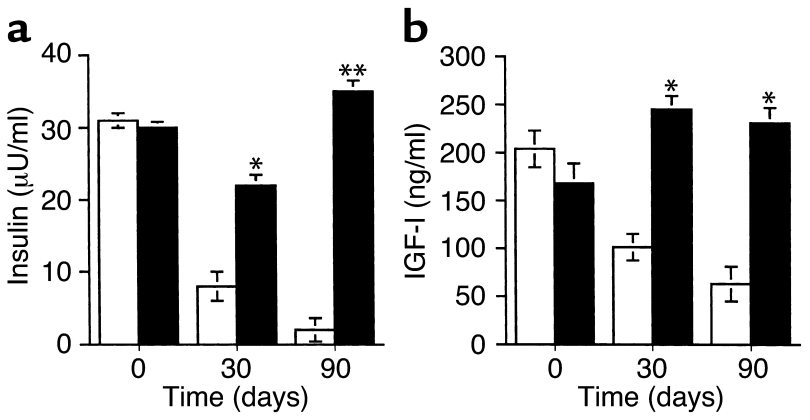

\section{Figure 5}

Serum concentrations of insulin and IGF-I before and after STZ treatment of mice. (a) Insulin and (b) IGF-I levels were determined as indicated in Methods. White bars, nontransgenic mice $(n=15)$; black bars, transgenic mice $(n=15)$. Results are mean \pm SEM of the indicated mice. ${ }^{*} P<0.05,{ }^{*} P<0.01$ vs. STZ-treated nontransgenic mice.

mice were normoinsulinemic (Figure 5a). Similarly, circulating levels of IGF-I were lower in STZ-treated nontransgenic than in STZ-treated transgenic mice (Figure 5b), which is a feature of diabetes (14). All hyperglycemic nontransgenic mice died, whereas all transgenic mice survived (Figure $4 \mathrm{~b}$ ). Hyperglycemic transgenic mice did not gain body weight. However, body weight rose after normalization of glycemia, and by 3 months it was similar to that of healthy nontransgenic and transgenic mice (Figure 3). In contrast, surviving STZ-treated nontransgenic mice showed lower body weight (Figure 3). Furthermore, 10-monthold STZ-treated transgenic mice and non-STZ-treated transgenic and nontransgenic mice showed similar blood glucose concentrations (STZ-Tg, $154 \pm 4 \mathrm{mg} / \mathrm{dl}$; $\mathrm{Tg}, 157 \pm 5 \mathrm{mg} / \mathrm{dl}$; and non-Tg, $155 \pm 3 \mathrm{mg} / \mathrm{dl}$ ) and serum insulin levels (STZ-Tg, $34 \pm 1 \mu \mathrm{U} / \mathrm{ml}$; Tg, $32 \pm 3$ $\mu \mathrm{U} / \mathrm{ml}$; and non- $\mathrm{Tg}, 30 \pm 5 \mu \mathrm{U} / \mathrm{ml}$ ).

Histological analysis of nontransgenic pancreas 3 months after STZ treatment showed islets with mild insulitis and loss of insulin-producing cells (Figure 2, $\mathrm{g}-\mathrm{i}$ ), and highly reduced $\beta$ cell mass (Figure $6 \mathrm{a}$ ). In contrast, STZ-treated transgenic mice had higher (about fivefold) $\beta$ cell mass than STZ-treated nontransgenic mice (Figure 6a) due to larger islets; they also had normal morphology (Figure 2, j-1), and small scattered clusters of insulin-producing cells (data not shown). However, $\beta$ cell mass of STZ-treated transgenic mice was lower than that of non-STZ-treated nontransgenic mice (Figure 6a). Although non-STZ-treated 6-monthold transgenic mice presented an increase of about 1.5fold in $\beta$ cell mass compared with nontransgenic mice (Tg, $1.32 \pm 0.2 \mathrm{mg}$; non- $\mathrm{Tg}, 0.87 \pm 0.16 \mathrm{mg} ; P<0.05$ ) (Figure 2, $\mathrm{m}$ and $\mathrm{n}$ ), they showed similar pancreatic insulin content $(\mathrm{Tg}, 6.5 \pm 0.5 \mu \mathrm{g}$ insulin $/ 100 \mathrm{mg}$ pancreas; non- $\mathrm{Tg}, 6.1 \pm 0.4 \mu \mathrm{g}$ insulin $/ 100 \mathrm{mg}$ pancreas). Furthermore, all these transgenic mice were normoglycemic and normoinsulinemic, indicating that IGF-I overexpression did not lead to hyperinsulinemia or hypoglycemia with age.
STZ-treated transgenic mice also showed an increase in insulin-positive cells budding from the ductal epithelium (as indicated by cytokeratin staining, Figure 6c), which is the site of neogenesis of new islets from ductal precursor cells (7). In addition, STZ-treated transgenic mice had higher neogenic $\beta$ cell mass (Figure $6 \mathrm{~b}$ ). Therefore, IGF-I production protected transgenic $\beta$ cells from destruction after STZ treatment and also increased $\beta$ cell mass and induced $\beta$ cell neogenesis.

Counteraction of diabetic alterations by IGF-I expression in $\beta$ cells of CD-1 mice. To further examine this IGF-I protective effect, transgenic mice were backcrossed to CD-1 mice to obtain transgenic mice in CD-1 genetic background. These mice are highly susceptible to develop insulitis, progressive $\beta$ cell destruction, and diabetes following multiple injections of subdiabetogenic doses of STZ (35). Two-month-old nontransgenic and transgenic mice of the $\mathrm{N} 4$ generation (about 94\% CD-1 background) presented similar glycemia (Tg, $139 \pm 6 \mathrm{mg} / \mathrm{dl}$; non- $\mathrm{Tg}, 142 \pm 5 \mathrm{mg} / \mathrm{dl}$ ), insuline$\mathrm{mia}(\mathrm{Tg}, 43 \pm 2 \mu \mathrm{U} / \mathrm{ml}$; non- $\mathrm{Tg}, 39 \pm 4 \mu \mathrm{U} / \mathrm{ml}$ ), and body weight (Tg, $38 \pm 0.9 \mathrm{~g}$; non- $\mathrm{Tg}, 38 \pm 0.5 \mathrm{~g}$ ). One month after STZ treatment, nontransgenic and transgenic mice were highly hyperglycemic, reaching blood glucose concentrations of about $600 \mathrm{mg} / \mathrm{dl}$ (Figure 7a). Afterward, STZ-treated nontransgenic mice had glycemic levels that surpassed the upper limit of measurement (Figure 7a) and remained very high after starvation (Figure $7 \mathrm{~b}$ ). These mice did not survive longer

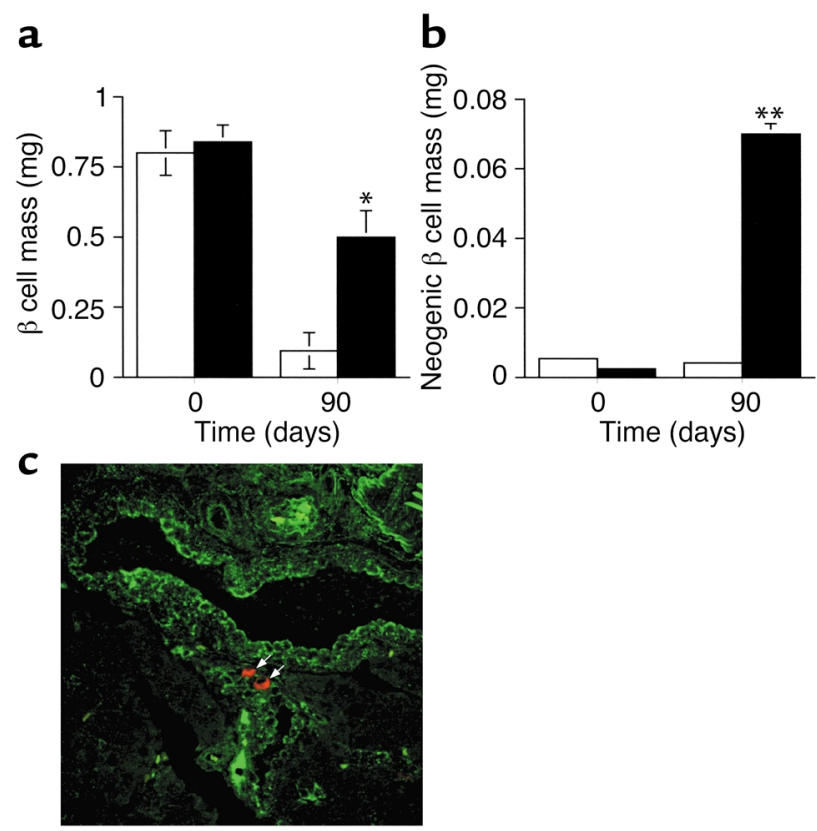

Figure 6

(a) $\beta$ Cell mass and (b) neogenic $\beta$ cell mass were determined in transgenic (black bars; $n=5$ ) and nontransgenic (white bars; $n=5$ ) pancreas before and 3 months after STZ treatment as described in Methods. (c) Neogenesis in STZ-treated transgenic pancreas. Cells immunostained for insulin (red) can be seen budding from the duct stained for cytokeratin (green) $(\times 400)$. Results are mean \pm SEM of the indicated mice. ${ }^{*} P<0.05,{ }^{*} P<0.01$ vs. STZ-treated nontransgenic mice. 


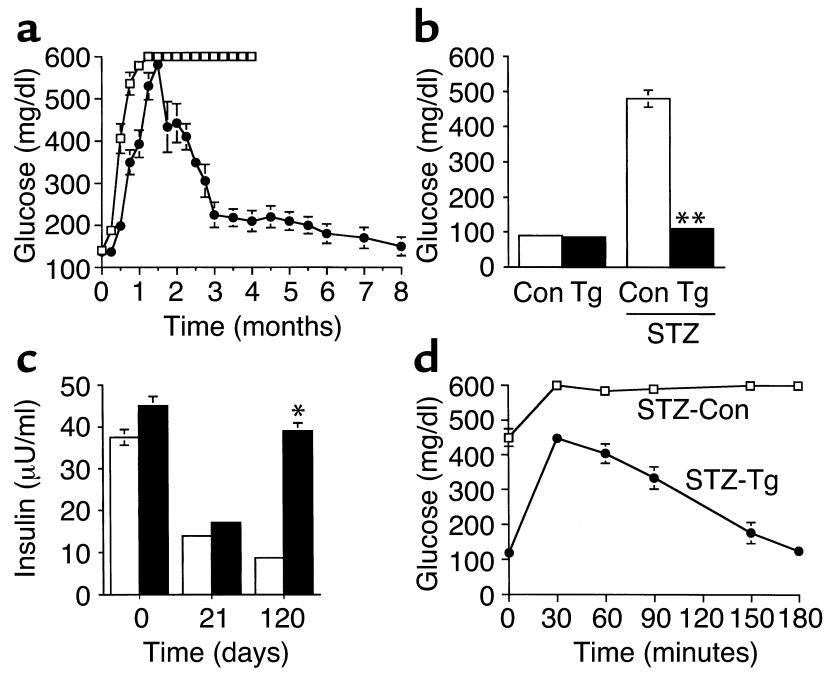

Figure 7

Blood glucose concentration of N4 CD-1 mice after STZ treatment. Blood glucose levels were measured in (a) fed nontransgenic (squares; $n=20)$ and transgenic (circles; $n=12$ ) mice, and in (b) nontransgenic (white bars; $n=10$ ) and transgenic (black bars; $n=12$ ) mice treated for 3 months with STZ and starved overnight. (c) Serum concentration of insulin was determined after STZ treatment in N4 CD-1 nontransgenic (white bars; $n=8$ ) and in transgenic (black bars; $n=6$ ) mice at the times indicated. (d) Intraperitoneal glucose tolerance test. Nontransgenic (squares; $n=6$ ) and transgenic (circles; $n=8$ ) mice treated for 3 months with STZ and starved overnight were given an intraperitoneal injection of $1 \mathrm{mg}$ of glucose/g of body weight. Blood samples were taken at the times indicated from the tail veins of the same animals. Results are mean \pm SEM of the indicated mice. ${ }^{*} P<0.05,{ }^{*} P<0.01 \mathrm{vs}$. STZ-treated nontransgenic mice.

than 4 months. In contrast, 2 months after STZ treatment, glycemia began to decrease in 12 of 17 transgenic mice. By 3 months these mice showed blood glucose levels of about $200 \mathrm{mg} / \mathrm{dl}$, and thereafter they remained normoglycemic in both fed (Figure 7a) and fasted (Figure 7b) conditions. The other 5 STZ-treated N4 transgenic mice, blood glucose levels decreased more slowly and by 6 months they were $350 \pm 20$ $\mathrm{mg} / \mathrm{dl}$ in fed and $110 \pm 15 \mathrm{mg} / \mathrm{dl}$ in starved conditions. Nevertheless, none of STZ-treated transgenic mice died. Three weeks after STZ treatment, both N4 nontransgenic and transgenic mice showed decreased insulinemia (Figure 7c). Normalization of hyperglycemia in transgenic mice was paralleled by the restoration of insulinemia to normal levels (Figure 7c). Furthermore, 8 months after STZ treatment, transgenic mice, compared with 10-month-old non-STZtreated transgenic and nontransgenic mice, showed similar glycemia (STZ-Tg, $152 \pm 4 \mathrm{mg} / \mathrm{dl} ; \mathrm{Tg}, 154 \pm 6$ $\mathrm{mg} / \mathrm{dl}$; and non-Tg, $149 \pm 5 \mathrm{mg} / \mathrm{dl}$ ) and insulinemia (STZ-Tg, $41 \pm 5 \mu \mathrm{U} / \mathrm{ml} ; \mathrm{Tg}, 42 \pm 5 \mu \mathrm{U} / \mathrm{ml}$; and non-Tg, $38 \pm 6 \mu \mathrm{U} / \mathrm{ml})$.

When an intraperitoneal glucose tolerance test was performed in overnight-starved mice 3 months after STZ treatment, transgenic animals showed lower blood glucose levels than nontransgenic mice (Figure 7d).
Furthermore, the increase in circulating glucose levels in transgenic mice was transient and they gradually returned to basal levels, while blood glucose concentration remained high in nontransgenic mice (Figure $7 \mathrm{~d})$. These results indicate that STZ-treated mice had a normal response to a glucose load. In addition, 3 months after STZ treatment the concentration of serum $\beta$-hydroxybutyrate was normalized in transgenic mice (Table 1). Transgenic mice also showed normal levels of circulating triglycerides and FFAs, which were increased in diabetic nontransgenic mice (Table 1).

One month after STZ treatment, fluid and food intake rose in both nontransgenic and transgenic N4 mice (Figure 8 , $a$ and $b$ ). These parameters increased progressively in STZ-treated nontransgenic mice, and by 3 months, fluid and food intake were ten- and threefold higher, respectively, indicating the severity of diabetes. However, with normalization of glycemia and insulinemia, normal fluid and food intake were recovered in STZ-treated $\mathrm{N} 4$ transgenic mice (Figure 8, a and b).

IGF-I expression in $\beta$ cells of STZ-treated CD-1 mice led to regeneration of endocrine pancreas. Histological analysis of pancreas was performed 2 weeks after STZ treatment, when mice were highly hyperglycemic. In contrast to non-STZ-treated mice, in which islets were spherical, islets from both STZ-treated nontransgenic and transgenic mice showed altered shape and insulitis (Figures 9 and 10). Insulin immunostaining revealed the loss of $\beta$ cells (Figure 9, a, b, d, and e), whereas glucagon immunostaining indicated $\alpha$ cell preservation (Figure $10, a, b, d, e)$. Although islets from both STZ-treated nontransgenic and transgenic mice showed lymphocytic infiltration, insulitis was more severe in nontransgenic mice (Figure 9, b and e; and Figure 10, b and e). STZ-treated transgenic mice had a high percentage of noninfiltrated islets and islets with less than $25 \%$ infiltration, whereas most of the nontransgenic islets had a high level of infiltration (data not shown), suggesting that IGF-I expression in $\beta$ cells attenuated insulitis development. Furthermore, to study whether IGF-I expression protected $\beta$ cells from STZ-induced apoptosis in vivo, we performed double immunohistochemical analysis of insulin and TUNEL to identify apoptotic $\beta$ cells. Before STZ treatment, no apoptotic $\beta$ cells were observed in either transgenic or nontransgenic islets, while insulin/TUNEL double positive cells were detect-

\section{Table 1}

Serum parameters

\begin{tabular}{lccc}
\hline & $\begin{array}{c}\beta \text {-Hydroxybutyrate } \\
(\mathrm{mmol} / \mathrm{l})\end{array}$ & $\begin{array}{c}\text { Triglycerides } \\
(\mathrm{mg} / \mathrm{dl})\end{array}$ & $\begin{array}{c}\text { FFA } \\
(\mathrm{mmol} / \mathrm{l})\end{array}$ \\
Con & $0.7 \pm 0.1$ & $160 \pm 17$ & $0.85 \pm 0.1$ \\
STZ-Con & $2.12 \pm 0.4$ & $237 \pm 46$ & $1.28 \pm 0.13$ \\
STZ-Tg & $0.66 \pm 0.16^{\mathrm{A}}$ & $144 \pm 22^{\mathrm{B}}$ & $0.91 \pm 0.17^{\mathrm{B}}$
\end{tabular}

Serum parameters from fed nontransgenic (Con) and transgenic ( $\mathrm{Tg}$ ) mice treated for 3 months with STZ were determined as described in Methods. Results are means \pm SEM of at least ten different animals in each group. ${ }^{A} P<0.01,{ }^{B} P<0.05$ vs. STZ-treated nontransgenic mice. 

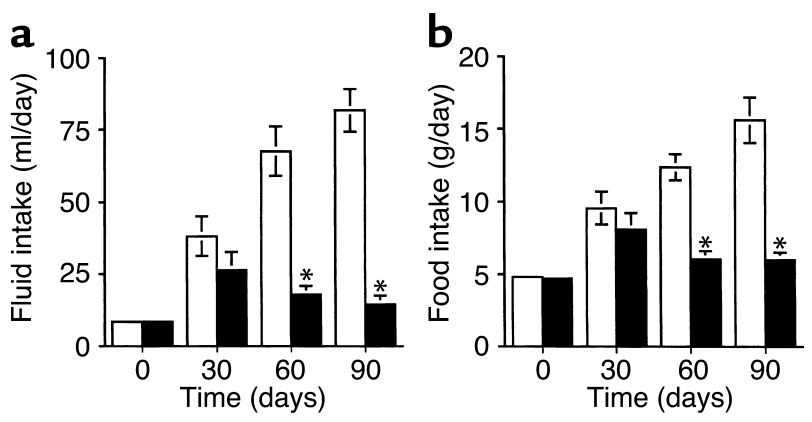

\section{Figure 8}

Fluid (a) and food (b) intake of nontransgenic (white bars) and transgenic (black bars) mice were measured at different times after STZ treatment. Results are mean \pm SEM of 12 transgenic and 10 nontransgenic mice. ${ }^{*} P<0.05$ vs. STZ-treated nontransgenic mice.

ed 3 and 8 days after STZ treatment (Figure 11). Although a similar percentage of apoptotic $\beta$ cells was observed in both groups of mice on day 3 , a significant decrease (about $40 \%$ ) was noted in transgenic mice 8 days after STZ treatment (Figure 11). These results suggest that IGF-I expression partially protected $\beta$ cells from apoptosis. Nevertheless, soon after STZ treatment, transgenic mice lost a significant number of $\beta$ cells, which led to the development of hypoinsulinemia and hyperglycemia (Figure 7).

Four months after STZ treatment, insulin immunostaining of nontransgenic pancreas showed small islets with few $\beta$ cells (Figure 9, c and i). However, glucagon immunostaining of nontransgenic pancreas revealed numerous $\alpha$ cells (Figure 10c). In contrast, insulin immunostaining of pancreas of normoglycemic STZ-treated N4 transgenic mice revealed a large number of islets without insulitis, and small scattered clusters of insulin-producing cells (Figure 9, $f$ and $j$ ). These islets had abnormal distribution of $\beta$ cells, since several cells in the islet core were not stained (Figure 9f), and glucagon-producing cells were randomly distributed throughout the islet core rather than at the periphery (Figure 10f). IGF-I staining colocalized with insulin-producing cells in these islets (Figure 12). Three months after STZ treatment, transgenic mice showed higher $\beta$ cell mass (about sevenfold) than diabetic nontransgenic mice (Figure 13a). These STZ-treated transgenic mice presented slightly lower (about 20\%) $\beta$ cell mass than did 6-month-old non-STZ-treated transgenic and nontransgenic mice, which showed similar $\beta$ cell mass (STZ-Tg, $1.45 \pm 0.4$ $\mathrm{mg}$; $\mathrm{Tg}, 1.83 \pm 0.6 \mathrm{mg}$; and non- $\mathrm{Tg}, 1.9 \pm 0.5 \mathrm{mg}$ ). This indicated that $\beta$ cell expression of IGF-I in N4 CD-1 transgenic mice did not lead to islet hyperplasia. Furthermore, the mass of insulin-producing cells budding from pancreatic ducts was also higher in STZtreated transgenic mice (Figure 13b). In addition, $\beta$ cell replication was greater (about threefold) in 2-month-old transgenic than in nontransgenic pancreas (Figure 13c). A similar increase in BrdU-positive $\beta$ cells was noted in transgenic islets 8 days after STZ treatment, but it was lower at 3 months, when mice recovered from hyperglycemia (Figure 13c). All these results suggest that normalization of $\beta$ cell mass in STZ-treated transgenic mice probably resulted from increased $\beta$ cell replication and neogenesis.

\section{Figure 9}

Immunohistochemical analysis of insulin expression in islets from N4 CD-1 mice. (a-f) Pancreata from 2-month-old non-STZtreated nontransgenic (Con) (a) and transgenic $(\mathrm{Tg})(\mathbf{d})$ mice, nontransgenic (b) and transgenic (e) mice treated for 2 weeks with STZ, and nontransgenic (c) and transgenic (f) mice treated for 4 months with STZ were analyzed. $\times 400$. (g-j) Pancreata from 6month-old non-STZ-treated nontransgenic (g) and transgenic (h) mice and nontransgenic (i) and transgenic $(\mathbf{j})$ mice treated for 4 months with STZ were analyzed. $\times 40$.

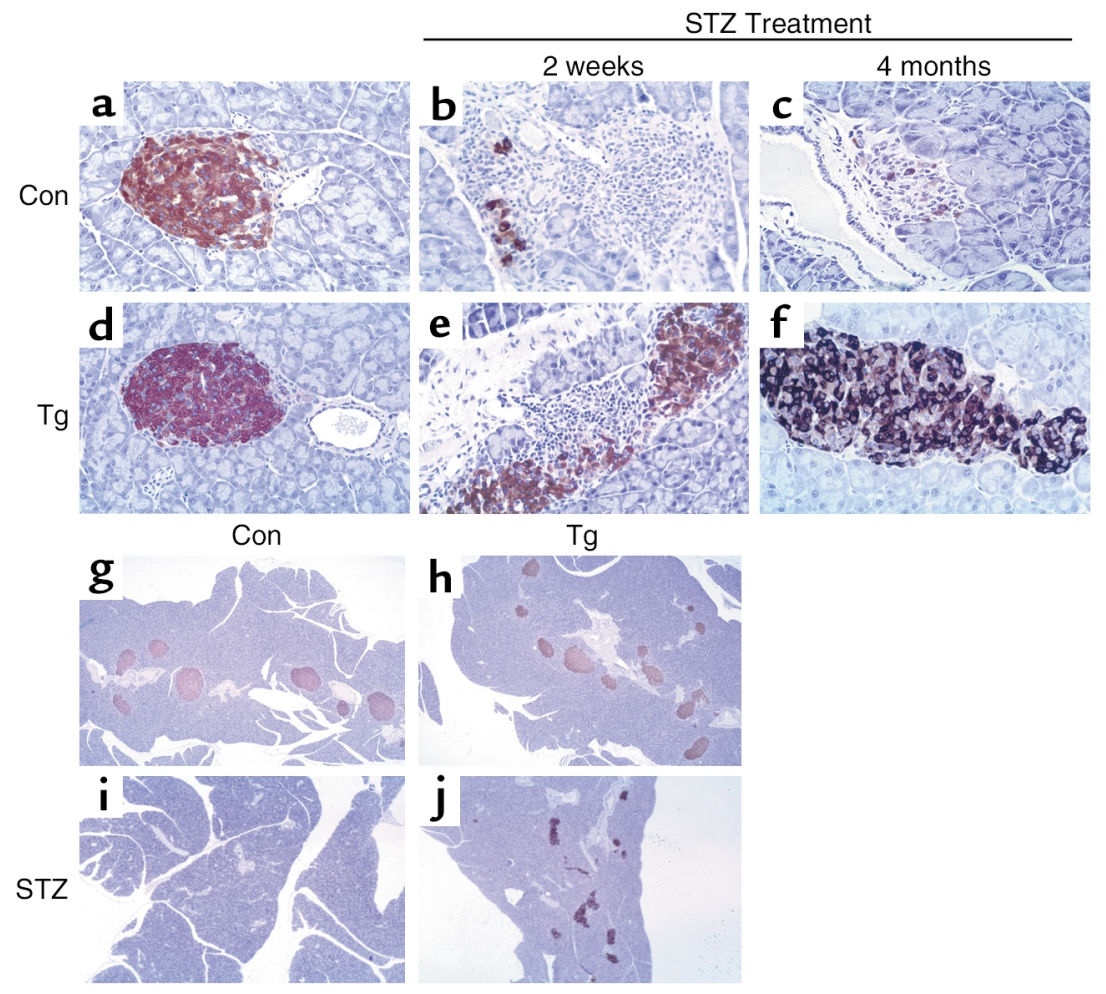




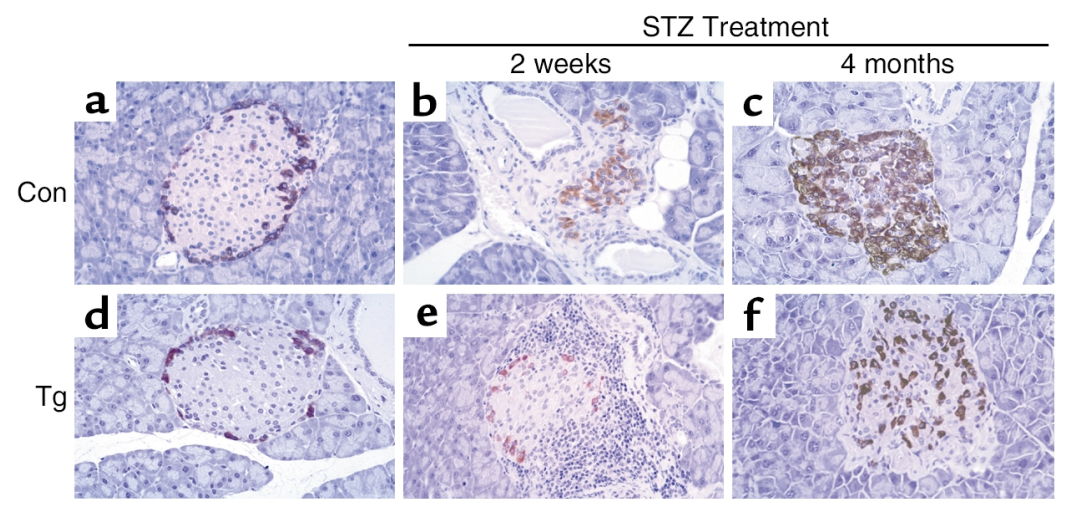

\section{Figure 10}

Immunohistochemical analysis of glucagon expression in islets from N4 CD-1 mice. Pancreata from 2-month-old non-STZ-treated nontransgenic (Con) (a) and transgenic $(\mathrm{Tg})(\mathbf{d})$ mice, nontransgenic (b) and transgenic (e) mice treated for 2 weeks with STZ, and nontransgenic (c) and transgenic (f) mice treated for 4 months with STZ were analyzed. $\times 400$.

\section{Discussion}

In this study we show that transgenic mice expressing IGF-I in $\beta$ cells presented high levels of immunoreactive IGF-I in insulin-producing $\beta$ cells. However, $\beta$ cell expression of IGF-I did not affect other organs, since nontransgenic and transgenic mice had similar serum IGF-I and body weight, suggesting an autocrine/paracrine role of IGF-I in the pancreas. Moreover, in adult mice the pancreas expresses IGF-I (43), which is independent of growth hormone $(14,44)$. Liver-specific IGF-I knockout mice show that although hepatic IGF-I is the main source of IGF-I in blood, it is not required for postnatal growth and development (45), which emphasizes the importance of the autocrine/paracrine role of IGF-I. Transgenic mice overexpressing IGF-II in $\beta$ cells also have low levels of circulating IGF-II (46), indicating an autocrine/paracrine interaction of IGF-II with pancreatic IGF-I receptors. In contrast, transgenic mice overexpressing IGF-I in the liver show high plasma levels of IGF-I and increased body weight $(47,48)$. However, they are normoglycemic and hypoinsulinemic (48), probably as a result of the increased IGF-I-induced glucose uptake by peripheral tissues and the subsequent compensatory decrease in insulin production. Similarly, an increase in body weight is noted in transgenic mice overexpressing growth hormone, which leads to high levels of circulating IGF-I (49, 50). However, these mice develop high islet hyperplasia, hyperinsulinemia, and insulin resistance $(51,52)$. Transgenic mice expressing IGF-I in $\beta$ cells were normoglycemic and normoinsulinemic, even when 10 months old, indicating that the expression of the transgene did not alter whole body glucose homeostasis.

To examine the ability of local IGF-I to counteract $\beta$ cell destruction and type 1 diabetes, transgenic mice were treated with STZ. Injection of multiple low doses of STZ leads to type 1 diabetes with or without insulitis, depending on mouse genetic background (35). Here we found that while STZ treatment led to loss of $\beta$ cell mass and diabetes in both C57BL/6-SJL and CD-1 mice, it induced high insulitis only in CD-1 mice. STZtreated C57BL/6-SJL nontransgenic mice became highly hyperglycemic, whereas C57BL/6-SJL transgenic mice expressing IGF-I in $\beta$ cells were less likely to develop overt diabetes and, 3 weeks after treatment, had blood glucose levels of no more than about $300 \mathrm{mg} / \mathrm{dl}$. This suggests that IGF-I expression in $\beta$ cells of these transgenic mice protected them against the oxidative and apoptotic effects of STZ. However, STZ-treated CD-1 mice showed progressive infiltration of inflammatory cells into the islets and, finally, overt $\beta$ cell destruction. Although islets from CD-1 transgenic mice had lymphocytic infiltration, the insulitis was milder than in CD-1 nontransgenics. Moreover, a reduction in $\beta$ cell apoptosis was noted in transgenic islets. This indicates that IGF-I production by CD- 1 transgenic islets partially protected them from destruction. All these findings agree with the protective effect of IGF-I against cytokine-mediated $\beta$ cell death in vitro (27-29). These results are also consistent with the finding that mice that are both heterozygous for null alleles of IGF-I receptor (Igf1r) and homozygous for null alleles of Irs-2 $\left(\right.$ Igfl $1 r^{+/-} /$Irs $\left.-2^{-/-}\right)$show marked reduction of $\beta$ cell mass, increased numbers of apoptotic cells, and increased expression of the proapoptotic protein $\mathrm{BAD}$ in their islets (19), indicating that IGF-I receptor/IRS-2 pathways protect $\beta$ cells from apoptosis in vivo (19). The results obtained in this double knockout model togeth-

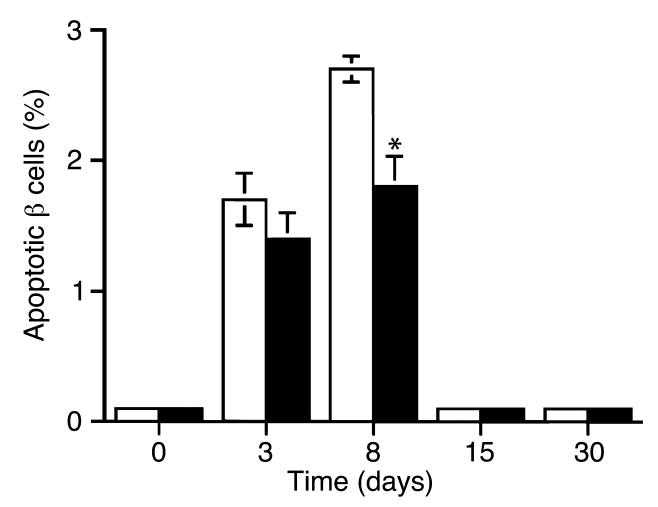

Figure 11

Analysis of apoptosis in STZ-treated mice. At the indicated times after STZ treatment, the percentage of insulin/TUNEL double positive cells was determined in transgenic (black bars) and nontransgenic (white bars) pancreas as indicated in Methods. Results are mean \pm SEM of five transgenic and five nontransgenic mice per group. ${ }^{*} P<0.05$ vs. STZ-treated nontransgenic mice. 

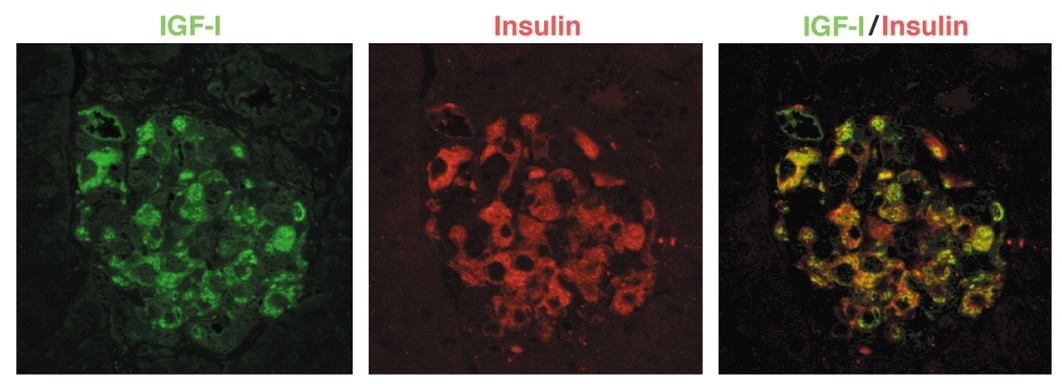

\section{Figure 12}

Colocalization of IGF-I and insulin in $\beta$ cells from transgenic mice. Four months after STZ treatment, pancreas sections of transgenic mice were coimmunostained for IGF-I (green) and insulin (red) as indicated in Methods. Sections $(5 \mu \mathrm{m})$ were photographed individually at $\times 600$ magnification and superimposed.

er with our study in the IGF-I transgenic mice suggest that production of IGF-I by $\beta$ cells might confer protective effects against an autoimmune response.

Furthermore, in the STZ-treated C57BL/6-SJL transgenic mice expressing IGF-I, the increased glycemia gradually returned to basal levels, after which mice remained normoglycemic and survived normally. These findings suggest that, in addition to the antiapoptotic role of IGF-I, its mitogenic effects contributed to the normalization of $\beta$ cell mass and glycemia in the STZtreated C57BL/6-SJL transgenic mice. However, CD-1 transgenic mice were highly hyperglycemic for the first 2 months, indicating that the loss of $\beta$ cells was higher than in the C57BL/6-SJL transgenic mice. Nevertheless, since all these mice recovered from STZ-induced alterations, this agrees with the induction of $\beta$ cell replication and neogenesis observed in these mice. Thus, our results suggest that, when overexpressed locally in $\beta$ cells in stress conditions that lead to $\beta$ cell destruction, IGF-I restored $\beta$ cell mass and normoinsulinemia. Furthermore, no compensatory increase in IGF-I production was observed in STZ-treated nontransgenic islets (Figure $2 \mathrm{~g}$ ), suggesting that endogenous IGF-I did not play a role in this process. These results are consistent with the induction of $\beta$ cell replication by IGF-I treatment in vitro (20) and with the observations in vivo that signaling through IGF-I receptor promotes $\beta$ cell development and proliferation (19). Thus, homozygous IRS-2-deficient mice (19, 53), mice both heterozygous for null alleles of Irs-1 and homozygous for null alleles of Irs-2 (Irs-1//-/Irs-2-/) (19), and mice both heterozygous for null alleles of IGF-I receptor (Igf1r) and homozygous for null alleles of Irs-2 $\left(\right.$ Igfl $1 r^{+/-} /$Irs-2 $\left.{ }^{--}\right)(19)$ all show marked reduction of $\beta$ cell mass and die from diabetes due to $\beta$ cell insufficiency. Similarly, while $\beta$ cell overexpression of active serine/threonine protein kinase Akt1, a mediator in the IGF-I receptor signaling pathway, leads to $\beta$ cell proliferation and islet hyperplasia $(54,55)$, mice deficient in ribosomal S6 kinase S6K1 ( $70^{56 k}$ ), a downstream target of activated Akt, have hypoinsulinemia and decreased islet cell mass (56).

Glucose also is one of the main stimuli for $\beta$ cell replication in vitro and in vivo $(57,58)$. Thus, the hyperglycemia noted soon after STZ treatment in transgenic mice expressing IGF-I may also have contributed to $\beta$ cell replication. Furthermore, uncontrolled islet cell proliferation was not observed in recovered STZ treated transgenic mice, which showed $\beta$ cell mass similar to that of healthy nontransgenic mice. This may also result from regulated expression of IGF-I by the RIP-I promoter. It is also compatible with a putative role of insulin in $\beta$ cell mass, in addition to a direct effect of IGF-I on $\beta$ cell proliferation and neogenesis. Mice lacking both insulin-1 and -2 genes show islet hyperplasia by abnormal proliferation of non-insulin-producing $\beta$ cells (59). Thus, a cooperative action between insulin and IGF-I leading to normal $\beta$ cell mass may have been established in our transgenic mice.

The new islets in the normoglycemic STZ-treated transgenic mice expressing IGF-I showed altered distribution of $\alpha$ cells, which no longer formed a mantle

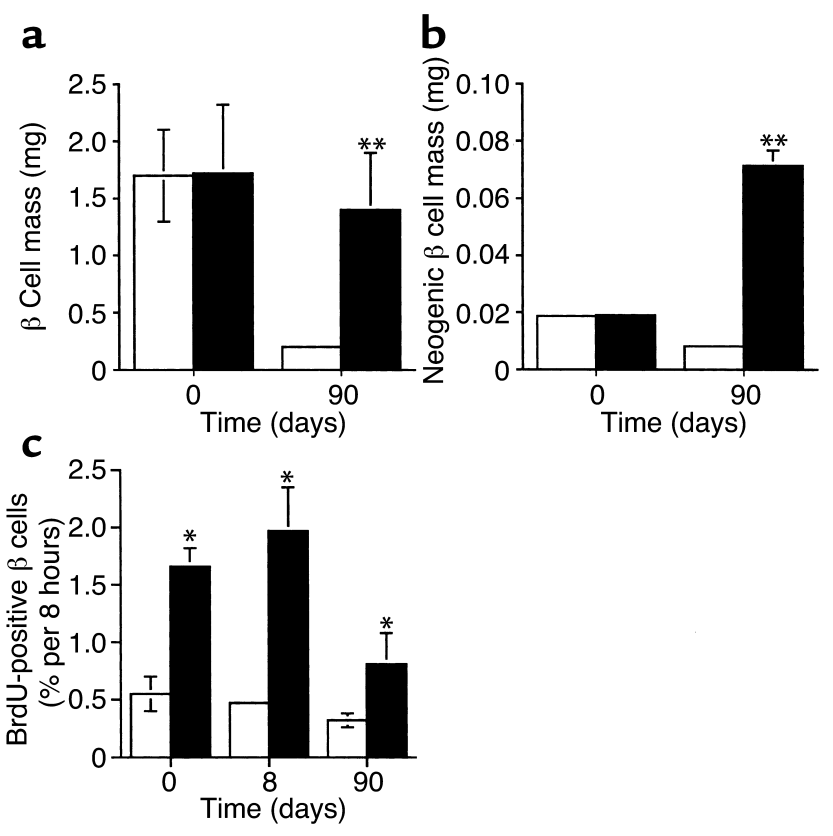

Figure 13

(a) $\beta$ Cell mass and (b) neogenic $\beta$ cell mass were determined in transgenic (black bars) and nontransgenic (white bars) pancreas before and 4 months after STZ treatment as described in Methods. (c) Analysis of $\beta$ cell replication. In sections immunostained for both non- $\beta$ cells and incorporated BrdU, the frequency of BrdU-positive $\beta$ cells was determined in nontransgenic and transgenic islets, both before and after STZ treatment, as indicated in Methods. Results are mean \pm SEM of five transgenic and five nontransgenic mice. ${ }^{*} P<0.05,{ }^{*} P<0.01$ vs. STZ-treated nontransgenic mice. 
around the $\beta$ cell core. After STZ treatment, numerous $\beta$ cells were destroyed, altering islet shape, and the surviving $\beta$ cells were mixed with $\alpha$ cells in these transgenic islets. Thereafter, the IGF-I-stimulated replication of pre-existing $\beta$ cells may have led to the disorganized islets of these mice. Nevertheless, these islets produced insulin, albeit with altered cell distribution, and transgenic mice recovered from diabetes. Islet cell disorganization is also detected in transgenic mice expressing IGF-II in $\beta$ cells (46), in mice lacking both insulin receptor and IRS-1 genes (60), and in mice overexpressing active Akt1 (55), suggesting an increased IGF-I receptor/IRS-2-mediated response. In contrast, transgenic mice overexpressing growth hormone are highly hyperinsulinemic and show high hyperplasia of islets $(51,52)$ but normal distribution of $\alpha$ cells (F. Bosch, unpublished observations).

Transgenic mice expressing IGF-II in $\beta$ cells show a threefold increase in islet mass that leads to hyperinsulinemia and insulin resistance and to mild type 2 diabetes when older (46). Similarly, Akt1 transgenic mice show a six- to eightfold increase in $\beta$ cell mass and hyperinsulinemia, although they were not insulinresistant at 6 weeks of age $(54,55)$, and long-term effects of Akt 1 overexpression have not yet been reported. IGF-I treatment of $\beta$ cell lines leads to phosphorylation and activation of Akt1 (61). However, transgenic mice expressing IGF-I were normoglycemic and normoinsulinemic, even when older, and this factor protected $\beta$ cells from apoptosis and favored islet regeneration after STZ treatment. The fact that IGF-I and IGF-II animals had different phenotypes may result from the ability of IGF-II to interact with, in addition to the IGF-I receptor, the insulin receptor as well (62). Human insulin receptor has two isoforms, A and B (IR-A and IR-B), resulting from alternative splicing of a small exon (63). The relative expression of the two isoforms varies in a tissue-specific manner $(63,64)$. IR-A is expressed mainly in the CNS but also in adult muscle, liver, and kidney $(63,64)$. Studies in fibroblast transfected with IR-A and -B show that IGF-II binds to IR-A with an affinity equal to that of IGF-II binding to the IGF-I receptor. IR-A activated by IGF-II elicits predominantly mitogenic rather than metabolic effects, which is associated with differential recruitment and activation of intracellular substrates (64). This might also happen in $\beta$ cells. Nevertheless, it is difficult to assess the relative role of insulin receptor- and IGF-I receptor-mediated response in IGF-I and IGF-II signaling in vivo in $\beta$ cells. It might be examined by crossing these transgenic mice overexpressing IGF-I or IGF-II with knockout mice lacking several intermediates in insulin receptor and IGF-I receptor signaling pathways.

In summary, our results indicate that the expression of IGF-I in $\beta$ cells restores $\beta$ cell mass and normoglycemia in mice that have lost $\beta$ cells and are highly hyperglycemic. Although most diabetic patients are identified after diabetes onset, when $\beta$ cell destruction is already severe, the present study suggests that $\beta$ cell destruction might be counteracted by genetically engineering the endocrine pancreas in vivo to express key factors that induce $\beta$ cell replication and neogenesis and that counteract the immune response. Although direct gene transfer to $\beta$ cells in vivo using viral vectors is a difficult task, progress in this field is expected in the future. When this is achieved, the effect of several "therapeutic genes" will be examined in diabetic animals. Our study suggests that IGF-I might be considered a candidate gene to be transferred to pancreatic islets as a new gene therapy approach for type 1 diabetes.

\section{Acknowledgments}

We thank R. Casamitjana for IGF-I measurements; and C.H. Ros, M. Moya, and A. Vilalta for technical assistance. A. Casellas and C. Costa were recipients of predoctoral fellowships from Fondo de Investigación Sanitaria and Ministerio de Educación y Cultura, respectively. J.C. Devedjian was a recipient of a postdoctoral fellowship from the Training and Mobility Program of the European Community. This work was supported by grants from the Fondo de Investigación Sanitaria (95/1758 and 98/1063), Direcció General de Recerca (1999SGR00101), Ramón Areces Foundation, and La Marató de TV3 Foundation (992710) of Spain.

1. Tisch, R., and McDevitt, H. 1996. Insulin-dependent diabetes mellitus. Cell. 85:291-297.

2. 1994. Chronic complications of diabetes. Blackwell Scientific Publications. Pickup, J.C., and Williams, G., editors. Oxford, United Kingdom. 313 pp.

3. Weir, G.C., and Bonner-Weir, S. 1997. Scientific and political impediments to successful islet transplantation. Diabetes. 46:1247-1256.

4. Efrat, S. 1998. Prospects for gene therapy of insulin-dependent diabetes mellitus. Diabetologia. 41:1401-1409.

5. Giannoukakis, N., Rudert, W.A., Robbins, P.D., and Trucco, M. 1999. Targeting autoimmune diabetes with gene therapy. Diabetes. 48:2107-2121.

6. Swenne, I. 1983. Effects of aging on the regenerative capacity of the pancreatic $\beta$-cell of the rat. Diabetes. 32:14-19.

7. Bonner-Weir, S. 2000. Islet growth and development in the adult. J. Mol. Endocrinol. 24:297-302.

8. Ramiya, V.K., et al. 2000. Reversal of insulin-dependent diabetes using islets generated in vitro from pancreatic stem cells. Nat. Med. 6:278-282.

9. Hellerstrom, C., and Swenne, I. 1991. Functional maturation and proliferation of fetal pancreatic $\beta$-cells. Diabetes. 40(Suppl. 2):89-93.

10. Rooman, I., Schuit, F., and Bouwens, L. 1997. Effects of vascular endothelial growth factor on growth and differentiation of pancreatic ductal epithelium. Lab. Invest. 76:225-232.

11. Rafaeloff, R., et al. 1997. Cloning and sequencing of the pancreatic islet neogenesis associated protein (INGAP) gene and its expression in islet neogenesis in hamsters. J. Clin. Invest. 99:2100-2109.

12. Lefebvre, V.H., et al. 1998. Culture of adult human islet preparations with hepatocyte growth factor and $804 \mathrm{G}$ matrix is mitogenic for duct cells but not for $\beta$-cells. Diabetes. 47:134-137.

13. Watanabe, T., et al. 1994. Pancreatic beta-cell replication and amelioration of surgical diabetes by reg protein. Proc. Natl. Acad. Sci. USA. 91:3589-3592.

14. Le Roith, D. 1997. Insulin-like growth factors. N. Engl. J. Med. 336:633-640.

15. Mathews, L.S., Norstedt, G., and Palmiter, R.D. 1986. Regulation of insulin-like growth factor I gene expression by growth hormone. Proc. Natl. Acad. Sci. USA. 83:9343-9347.

16. Smith, F.E., Rosen, K.M., Villa-Komaroff, L., Weir, G.C., and BonnerWeir, S. 1991. Enhanced insulin-like growth factor I gene expression in regenerating rat pancreas. Proc. Natl. Acad. Sci. USA. 88:6152-6156.

17. Hayakawa, H., et al. 1996. Induction and involvement of endogenous IGF-I in pancreas regeneration after partial pancreatectomy in the dog. J. Endocrinol. 149:259-267.

18. Van Schravendijk, C.F.H., Foriers, A., Van den Brande, J.L., and Pipeleers, D.G. 1987. Evidence for the presence of type 1 insulin-like growth factor receptors on rat pancreatic A and B cells. Endocrinology. 121:1784-1788. 
19. Withers, D.J., et al. 1999. Irs- 2 coordinates Igf- 1 receptor-mediated $\beta$-cell development and peripheral insulin signaling. Nat. Genet. 23:32-40.

20. Hügl, S.R., White, M.F., and Rhodes, C.J. 1998. Insulin-like growth factor I (IGF-I)-stimulated pancreatic $\beta$-cell growth is glucose-dependent: synergistic activation of insulin receptor substrate-mediated signal transduction pathways by glucose and IGF-I in Ins-1 cells. J. Biol. Chem. 273:17771-17779.

21. Myers, M.G., et al. 1994. Insulin receptor substrate-1 mediates phosphatidylinositol 3-kinase and $\mathrm{p} 70^{\mathrm{S} 6 \mathrm{~K}}$ signaling during insulin, insulinlike growth factor-1, and interleukin-4 stimulation. J. Biol. Chem. 269:28783-28789.

22. Dudek, H., et al. 1997. Regulation of neuronal survival by the serine-threonine protein kinase Akt. Science. 275:661-665.

23. Kennedy, S.G., et al. 1997. The PI 3-kinase/Akt signaling pathway delivers an anti-apoptotic signal. Genes Dev. 11:701-713.

24. Kulik, G., Klippel, A., and Weber, M.J. 1997. Antiapoptotic signaling by the insulin-like growth factor I receptor, phosphatidylinositol 3-kinase, and Akt. Mol. Cell. Biol. 17:1595-1606.

25. Datta, S.R., et al. 1997. Akt phosphorylation of BAD couples survival signals to the cell-intrinsic death machinery. Cell. 91:231-241.

26. Peruzzi, F., et al. 1999. Multiple signaling pathways of the insulin-like growth factor 1 receptor in protection from apoptosis. Mol. Cell. Biol. 19:7203-7215

27. Mabley, J.G., Belin, V., John, N., and Green, I.C. 1997. Insulin-like growth factor I reverses interleukin-1 $\beta$ inhibition of insulin secretion, induction of nitric oxide synthase and cytokine-mediated apoptosis in rat islets of Langerhans. FEBS Lett. 417:235-238.

28. Harrison, M., et al. 1998. Growth factor protection against cytokineinduced apoptosis in neonatal rat islets of Langerhans: role of Fas. FEBS Lett. 435:207-210.

29. Castrillo, A., Bodelón, O.G., and Boscá, L. 2000. Inhibitory effect of IGFI on type 2 nitric oxyde synthase expression in Ins- 1 cells and protection against activation-dependent apoptosis: involvement of phosphatidylinositol 3-kinase. Diabetes. 49:209-217.

30. Giannoukakis, N., et al. 2000. Prevention of beta cell dysfunction and apoptosis activation in human islets by adenoviral gene transfer of the insulin-like growth factor I. Gene Ther. 7:2015-2022.

31. Kaino, Y., Hirai, H., Ito, T., and Kida, K. 1996. Insulin-like growth factor I (IGF-I) delays the onset of diabetes in non-obese diabetic (NOD) mice. Diabetes Res. Clin. Pract. 34:7-11.

32. Bergerot, I., Fabien, N., Maguer, V., and Thivolet, C. 1995. Insulin-like growth factor I (IGF-I) protects NOD mice from insulitis and diabetes. Clin. Exp. Immunol. 102:335-340.

33. Bell, G.I., Stempien, M.M., Fong, N.M., and Rall, L.B. 1986. Sequences of liver cDNAs encoding two different mouse insulin-like growth factor I precursors. Nucleic Acids Res. 14:7873-7882.

34. Valera, A., et al. 1994. Expression of Glut-2 antisense RNA in $\beta$-cells of transgenic mice leads to diabetes. J. Biol. Chem. 269:28543-28546.

35. Rossini, A., Appel, M.C., Williams, R.M., and Like, A.A. 1977. Genetic influence of the streptozotocin-induced insulitis and hyperglycemia. Diabetes. 26:916-920.

36. Huang, X., Hultgren, B., Dybdal, N., and Stewart, T.A. 1994. Islet expression of interferon-alpha precedes diabetes in both the BB rat and streptozotocin-treated mice. Immunity. 1:469-478.

37. O’Brien, B.A., Harmon, B.V., Cameron, D.P., and Allan, D.J. 1996. Betacell apoptosis is responsible for the development of IDDM in the multiple low-dose streptozotocin model. J. Pathol. 178:176-181.

38. Turk, J., Corbett, J.A., Ramanadham, S., Bohrer, A., and Daniel, L. 1993. Biochemical evidence for nitric oxide formation from streptozotocin in isolated pancreatic islets. Biochem. Biophys. Res. Commun. 197:1458-1464.

39. Mandrup-Poulsen, T. 1996. The role of interleukin-1 in the pathogenesis of IDDM. Diabetologia. 39:1005-1029.

40. Burkart, V., et al. 1999. Mice lacking the poly(ADP-ribose) polymerase gene are resistant to pancreatic beta-cell destruction and diabetes development induced by streptozotocin. Nat. Med. 5:314-319.

41. Boswald, M., Harasim, S., and Maurer-Schultze, B. 1990. Tracer dose and availability time of thymidine and bromodeoxyuridine: application of bromodeoxyuridine in cell kinetic studies. Cell Tissue Kinet. 23:169-181.
42. Swenne, I. 1982. The role of glucose in the in vitro regulation of cell cycle kinetics and proliferation of fetal pancreatic B-cells. Diabetes. 31:754-760.

43. Calvo, E.L., Bernatchez, G., Pelletier, G., Iovanna, J.L., and Morisset, J. 1997. Downregulation of IGF-I mRNA expression during postnatal pancreatic development and overexpression after subtotal pancreatectomy and acute pancreatitis in the rat pancreas. J. Mol. Endocrinol. 18:233-242.

44. Mathews, L.S., Norstedt, G., and Palmiter, R.D. 1986. Regulation of insulin-like growth factor I gene expression by growth hormone. Proc. Natl. Acad. Sci. USA. 83:9343-9347.

45. Yakar, S., et al. 1999. Normal growth and development in the absence of hepatic insulin-like growth factor I. Proc. Natl. Acad. Sci. USA. 96:7324-7329.

46. Devedjian, J.C., et al. 2000. Transgenic mice overexpressing insulin-like growth factor II in $\beta$-cells develop type 2 diabetes. J. Clin. Invest. 105:731-740.

47. Mathews, L.S., et al. 1988. Growth enhancement of transgenic mice expressing human insulin-like growth factor I. Endocrinology. 123:2827-2833

48. Quaife, C.J., et al. 1989. Histopathology associated with elevated levels of growth hormone and insulin-like growth factor I in transgenic mice. Endocrinology. 124:40-48.

49. Palmiter, R.D., et al. 1982. Dramatic growth of mice that develop from eggs microinjected with metallothionein-growth hormone fusion genes. Nature. 300:611-615.

50. McGrane, M.M., et al. 1988. Tissue-specific expression and dietary regulation of a chimeric phosphoeneolpyruvate carboxykinase/bovine growth hormone gene in transgenic mice. J. Biol. Chem. 263:11443-11451.

51. Parsons, J.A., Bartke, A., and Sorenson, R.L. 1995. Number and size of islets of Langerhans in pregnant, human growth hormone-expressing transgenic, and pituitary dwarf mice: effect of lactogenic hormones. Endocrinology. 136:2013-2021.

52. Valera, A., et al. 1993. Glucose metabolism in transgenic mice containing a chimeric P-enolpyruvate carboxykinase/bovine growth hormone gene. FASEB J. 7:791-800

53. Withers, D.J., et al. 1998. Disruption of IRS- 2 causes type 2 diabetes. Nature. 391:900-903.

54. Tuttle, R.L., et al. 2001. Regulation of pancreatic beta-cell growth and survival by the serine/threonine protein kinase Akt1/PKBalpha. Nat. Med. 7:1133-1137.

55. Bernal-Mizrachi, E., Wen, W., Stahlhut, S., Welling, C.M., and Permutt, M.A. 2001. Islet beta cell expression of constitutively active Akt1/PKB alpha induces striking hypertrophy, hyperplasia, and hyperinsulinemia. J. Clin. Invest. 108:1631-1638. DOI:10.1172/JCI200113785.

56. Pende, M., et al. 2000. Hypoinsulinaemia, glucose intolerance and diminished beta-cell size in S6K1-deficient mice. Nature. 408:994-997.

57. Bonner-Weir, S., Deery, D., Leahy, J.L., and Weir, G.C. 1989. Compensatory growth of pancreatic $\beta$-cells in adult rats after short-term glucose infusion. Diabetes. 38:49-53.

58. Bonner-Weir, S., and Smith, F.E. 1994. Islet growth and the growth factors involved. Trends in Endocrinology and Metabolism. 5:60-64.

59. Duvillie, B., et al. 1997. Phenotypic alterations in insulin-deficient mutant mice. Proc. Natl. Acad. Sci. USA. 94:5137-5140.

60. Bruning, J.C., et al. 1997. Development of a novel polygenic model of NIDDM in mice heterozygous for IR and IRS-1 null alleles. Cell. 21:561-572.

61. Holst, L.S., et al. 1998. Protein kinase B is expressed in pancreatic beta cells and activated upon stimulation with insulin-like growth factor I. Biochem. Biophys. Res. Commun. 250:181-186.

62. Morrione, A., et al. 1997. Insulin-like growth factor II stimulates cell proliferation through the insulin receptor. Proc. Natl. Acad. Sci. USA. 94:3777-3782.

63. Moller, D.E., Yokota, A., Caro, J.F., and Flier, J.S. 1989. Tissue-specific expression of two alternatively spliced insulin receptor mRNAs in man. Mol. Endocrinol. 3:1263-1269.

64. Frasca, F., et al. 1999. Insulin receptor isoform A, a newly recognized, high-affinity insulin-like growth factor II receptor in fetal and cancer cells. Mol. Cell. Biol. 19:3278-3288. 